\title{
The Worst Revolt of the Bisitun Crisis: A Chronological Reconstruction of the Egyptian Revolt under Petubastis IV
}

\author{
Uzume Z. WiJnsma, Leiden University*
}

When Darius I killed "Gaumata" and grabbed the Persian throne in $522 \mathrm{BC}$, a series of revolts broke out against him. Babylonia, Elam, Media, Sattagydia, Egypt, and so forth - almost the entire empire - saw the rise of "liar-kings" who rejected the legitimacy of Darius as emperor and claimed royal titles for themselves. Sadly for them, Darius was not so easily defeated. He and his loyal generals waged war against the rebel armies, crushed them, captured their leaders, and executed them for all to see. Some of them were beheaded, others impaled; but whichever method was chosen, their bodies must have been a firm reminder that to revolt against Darius the Achaemenid meant that an inevitable and humiliating death was coming your way.

We know most of this from the Bisitun inscription, of course. ${ }^{1}$ This monumental inscription on rock was

\footnotetext{
* This paper was written within the framework of the ERC CoG Persia and Babylonia project (682241). I wish to express my gratitude to Olaf Kaper and Caroline Waerzeggers for their time, support, and valuable feedback; and I thank the anonymous reviewers of JNES for their comments and suggestions. Any possible errors that remain are entirely my own.

${ }^{1}$ For a translation and a comparative study of all versions of Bisitun, see Chul-Hyun Bae, Comparative Studies of King Darius's Bisitun Inscription (PhD diss., Harvard University, 2001). For a convenient English translation of the main text and a chronological
}

written in the Zagros mountains near modern-day Bisitun. It tells the story of Darius' rise to power and the wars he waged in his first year on the throne. Or, better put, it tells the official imperial version of that story, a version which was subsequently propagated throughout the empire, on different media and in different languages. ${ }^{2}$ Whether the inscription actually tells us the whole story, or a true story, is debatable. ${ }^{3}$ But it is the only story we have. Later Greco-Roman authors merely retell it (with some details changed), and omit more than they add, while sources contemporary to the revolt, which might verify or refute the tale, are extremely rare. Only the dense cuneiform record in Babylonia corroborates a part of the Bisitun text. But what about the other regions? What do we really know about their role in the revolt and fate after 522 BC?

reconstruction of the revolts and battles, see Amélie Kuhrt, The Persian Empire: A Corpus of Sources from the Achaemenid Period (London, 2007), 140-57. All paragraphs marked $(\$)$ in this article refer to Kuhrt's translation.

${ }^{2}$ Ibid., 158; see also Jonas C. Greenfield and Bezalel Porten, The Bisitun Inscription of Darius the Great: Aramaic Version (London, 1982).

${ }^{3}$ On the reliability of the Bisitun text, see Kuhrt, Persian Empire, 135-40.

${ }^{4}$ Other regions have left us no textual sources for the years in question. For the Babylonian, Egyptian and Greco-Roman sources, see below. 
The role and fate of Egypt - which had only just been conquered by Cambyses - is especially obscure. The Bisitun inscription tells us that Egypt rebelled at the turn of $522 / 521 \mathrm{BC}$, together with a host of other countries $(\$ 21)$; but whereas the other countries are elaborately described as defeated, Egypt is never mentioned again. No campaign against the Two Lands is recorded, nor is the name of any Egyptian as a "liar-king." This makes the revolt unique in the entire Bisitun narrative, ${ }^{5}$ and it has created confusion and disagreement among modern-day scholars. Some are skeptical that the revolt ever existed (in one case suggesting that perhaps "Egypt" in the Bisitun text was simply a scribal mistake ${ }^{6}$, while others argue that the revolt lasted at least three years until it was thwarted in $518 \mathrm{BC}$ (which would make it the worst revolt of the entire Bisitun crisis). ${ }^{7}$ There is also an in-between option, as some accept that the revolt took place, but claim that it lasted for only a couple of months and/ or that it was confined to the north of Egypt. ${ }^{8}$ No consensus has been reached on any of these scenarios.

${ }^{5}$ See Christopher Tuplin, "Darius' Suez Canal and Persian Imperialism," in Asia Minor and Egypt: Old Cultures in a New Empire, ed. Heleen Sancisi-Weerdenburg and Amélie Kuhrt (Leiden, 1991), 264. It should be noted that the entire western periphery of the empire (save the single mention of Egypt) is ignored in the Bisitun inscription, even though there may have been some troubles in, e.g., Asia Minor (see Pierre Briant, From Cyrus to Alexander: A History of the Persian Empire, trans. Peter Daniels [Winona Lake, IN, 2002], 115-16).

${ }^{6}$ Friedrich K. Kienitz, Die politische Geschichte Ägyptens vom 7. bis zum 4. Jahrhundert vor der Zeitwende (Berlin, 1953), 60 n. 4; Marc Rottpeter, "Initiatoren und Träger der 'Aufstände' im persischen Ägypten," in Ägypten unter fremden Herrschern zwischen persischer Satrapie und römischer Provinz, ed. Stefan Pfeiffer (Frankfurt am Main, 2007), 14.

${ }^{7}$ Richard A. Parker, "Darius and His Egyptian Campaign," AJSLL 58/4 (1941): 373-77; George G. Cameron, "Darius, Egypt, and the 'Lands Beyond the Sea'," JNES 2/4 (1943): 30912; Olaf Kaper, "Petubastis IV in the Dakhla Oasis: New Evidence About an Early Rebellion Against Persian Rule and Its Suppression in Political Memory," in Political Memory in and after the Persian Empire, ed. Jason Silverman and Caroline Waerzeggers (Atlanta, 2015), 142-43.

${ }^{8}$ Briant mentions the possibility of an Egyptian revolt, but claims that the relevant rebel-king "disappeared a few months later, doubtless shown the error of his ways and executed by the satrap Aryandes" (Briant, Cyrus to Alexander, 115, without further arguments or references). Jean Yoyotte ("Pétoubastis III," RdE 24 [1972]: 223) thinks that he came from the Delta and that Persian garrisons and Egyptian collaborators will have ensured that he had "un pouvoir précaire et territorialement restraint" (without further arguments or references). I am not sure why Yoyotte thinks that the rebellion "ne dura guère au-delà de $520[\mathrm{BC}]$," because he re-
Over the years, new and possibly relevant sources for the Egyptian revolt have been published. An updated discussion of the evidence is still lacking, however. It is the aim of the present paper to fill that gap and breathe new life into the debate. I will review all of the relevant sources in chronological order (see also Table 1, pp. 160-61) and provide a new discussion of their significance and utility. In the end, I will argue that the Egyptian revolt was indeed the worst (in terms of duration) of the whole Bisitun crisis: it may have lasted two to three years before it was eventually defeated; and it reached well beyond the confines of northern Egypt. ${ }^{9}$

\section{Dating System}

Before we embark on a chronological reconstruction, some notes on the dating system are in order. The Persian and Egyptian way of dating were different from one another. The Persians had adopted the Babylonian system whereby a new king received an "accession year" (or "Year 0") from the day that he ascended the throne until the Babylonian New Year on 1 Nisannu. Year I was only counted from I Nisannu onwards, until the next New Year would begin Year 2. The Egyptians, however, counted a king's accession year directly as Year 1 . This year would last from the day of accession until the Egyptian New Year on 1 Thot, on which they would switch to Year 2. In other words, the systems were basically the same, but with the impor-

fers to the old reconstructions by Parker, "Darius and his Egyptian Campaign," and Cameron, "Darius," both of whom claim that the rebellion may have lasted until 518 BC. The only other reference in Yoyotte is to an article by V. V. Struve, to which I have no access (see Yoyotte, "Pétoubastis": 223). Stephen Ruzicka follows the old chronology given by Parker, but claims that there were several Delta dynasts at the time, despite the Persians managing to retain their hold on Memphis (Trouble in the West: Egypt and the Persian Empire, 525-332 BCE [New York, 2012], 23, without further arguments or references).

${ }^{9}$ My conclusion that the revolt may have lasted from 522/521 BC to 519/518 BC echoes that of Parker, "Darius and his Egyptian Campaign." Parker's arguments, however, are different and at times problematic: e.g., he takes the passage by Polyaenus at face value, though it was written down seven centuries after the Bisitun crisis and without indication of what it was based on. Parker does the same with the Herodotean passage about Aryandes. A strong connection between the revolt and Aryandes is therefore implied on the basis of the Greco-Roman evidence. Other than that, sources that were only published or excavated after 1941 (notably the Egyptian sources for Petubastis IV; see below) are of course excluded from Parker's reconstruction. 
tant differences that the Egyptians did not recognize a Year 0 for any king, and that the Egyptian and Babylonian New Years occurred in different months of the year. These two systems somehow had to be married to each other when the Persians conquered Egypt. ${ }^{10}$

It has been convincingly argued that Cambyses conquered Egypt in the first months of 526 BC when he was still in his third (Babylonian) regnal year. ${ }^{11}$ At some point in his reign, a policy must have been created as to how to date the regnal years of Persian kings within the Egyptian dating system. To maintain a certain cohesion between the two systems, it is probable that Egypt started dating to Cambyses Year 4 at some point in $526 \mathrm{BC}$, after 1 Nisannu (9 April 526 BC) but before 1 Thot (2 January $525 \mathrm{BC}$ ). In other words, Egypt recognized a Year 3 of Cambyses in 526 BC but switched to Year 4 in the same year, in conjunction with the Babylonian dating system. Subsequently, the Egyptians would have switched to Year 5 on 1 Thot at the end of the same year (2 January $525 \mathrm{BC}$ ), while the Babylonians would not switch to Year 5 until 1 Nisannu of 525 вс (29 March 525 вс). In this way, the two systems would line up for the majority of the year while only the first few months of every Egyptian year (or the last few months of every Babylonian year) would diverge, with Egypt's regnal years one higher than those in contemporary Babylonia. ${ }^{12}$

\footnotetext{
${ }^{10}$ Richard A. Parker, "Persian and Egyptian Chronology," AJSLL 58/3 (1941); Leo Depuydt, "Regnal Years and Civil Calendar in Achaemenid Egypt," JEA 81 (1995). Leo Depuydt has also considered the possibility that the Persians used another system besides the Babylonian one, namely "accession dating": see his "Evidence for Accession Dating under the Achaemenids," JAOS 115/2 (1995). However, the evidence for this proposal is slim. I will only consider the implications of accession dating in the case of Darius' Bisitun inscription (where I think it likely to have been used).

${ }^{11}$ Joachim F. Quack, "Zum Datum der persischen Eroberung Ägyptens unter Kambyses,” JEH 4 (2011).

${ }^{12}$ All dates in the present article are proleptic Julian and based on the following online date converters: http://aegyptologie. online-resourcen.de/latePeriod and https://www.staff.science. uu.nl/ gent0113/babylon/babycal_converter.htm (accessed May 2018). Note that the Egyptian converter is problematic, as it has not incorporated recent insights, which would result in deleting the fictional 45th regnal year of Amasis, reducing Psamtik III's reign to mere months instead of years, and converting Cambyses' regnal years to $4-8$ instead of $1-4$, with his first year (=Year $3 / 4)$ referring to $526 \mathrm{BC}$ instead of $525 \mathrm{BC}$ (cf. Quack, "Zum Datum der persischen Eroberung Ägyptens"). I have amended this in my dates, e.g., the dates for Cambyses' first year of rule in Egypt are extracted from the first year of Psamtik III in the date converter.
}

\section{The Bisitun Crisis: Introduction}

The Bisitun crisis began at some point after Cambyses' conquest of Egypt in $526 \mathrm{BC}$ and just before his death in 522 вс. The Bisitun inscription gives no dates for this earlier part of the story, nor does it mention what happened in the intervening four years. But we know from external sources that Cambyses probably stayed in Egypt after his conquest of the country, and that he had to travel back to Iran when the Bisitun troubles began. ${ }^{13}$ Why the troubles began is debated; but what follows summarizes Darius' version of events.

According to the Bisitun inscription, Cambyses left for Egypt after having killed his own brother, Bardiya. No one knew about the murder, however, and a man called Gaumata eventually used this ignorance to his own benefit: Gaumata pretended to be Cambyses' brother Bardiya, still alive and well, and rebelled on 11 March 522 BC. Many people joined Gaumata/Bardiya (henceforth "Bardiya I") in his revolt, and he became king on the first of July. Cambyses, presumably on his way back to Iran, died before he could solve the matter. But Darius, a man who was not a direct member of the royal family, decided to kill Bardiya I when no one else dared to (on 29 September 522 вC). He subsequently became king himself. Not everyone agreed with Darius' claim to the throne, however. Revolts broke out all across the empire, with several men claiming to be king in their own region and descendants of ancient royalty. Darius portrayed these dissenters as "liarkings," and tells us that he thwarted all of the revolts within his first year on the throne. Additions to the Bisitun inscription further tell us that Darius campaigned against Elam and Scythia in his second and third years. This is where the Bisitun inscriptions ends, and where the troubles for the historian begin.

\section{The Egyptian Documentary Gap}

How the tumultuous events of 522 BC played out in Egypt is difficult to discern. We have very few sources for the period in question. The four years of

\footnotetext{
${ }^{13}$ This is implied both by the Bisitun inscription, according to which troubles at court began after Cambyses' departure for Egypt ( $\$ 10$, without mention of his return), and by the elaborate description of Cambyses' activities in Egypt (and further forays into, e.g., Nubia) in the Histories of Herodotus, who furthermore claimed that Cambyses died on his way back to Susa in 522 вс (Hist. III 64). On Cambyses' departure from Egypt and his death, see further below.
} 
Table 1-Chronology of the Bisitun crisis until the first documents dated to Darius appear in Egypt ${ }^{\mathrm{a}}$

\begin{tabular}{|c|c|c|c|}
\hline Date $(B C)$ & Egypt & Babylonia & Bisitun \\
\hline March $522 B C$ & & & 11 March: Bardiya rebels. \\
\hline April 522 & $\begin{array}{l}\text { April(?): last document dated } \\
\text { to Cambyses. }\end{array}$ & $\begin{array}{l}18 \text { April: last document dated to } \\
\text { Cambyses. April/May: first documents } \\
\text { dated to Bardiya I. }\end{array}$ & \\
\hline \multicolumn{4}{|l|}{ May 522} \\
\hline \multicolumn{4}{|l|}{ June 522} \\
\hline July 522 & & & $\begin{array}{l}\text { I July: Bardiya becomes king. After- } \\
\text { wards: Cambyses dies. }\end{array}$ \\
\hline August 522 & & $\begin{array}{l}30 \text { August: first document dated to } \\
\text { Nebuchadnezzar III. }\end{array}$ & \\
\hline September 522 & & $\begin{array}{l}20 \text { September: last document dated to } \\
\text { Bardiya I. }\end{array}$ & $\begin{array}{l}29 \text { September: Darius kills Bardiya. } \\
\text { Afterwards: Darius becomes king; Elam } \\
\text { and Babylonia rebel. A campaign is sent } \\
\text { against Elam. }\end{array}$ \\
\hline \multicolumn{4}{|l|}{ October 522} \\
\hline \multicolumn{4}{|l|}{ November 522} \\
\hline December 522 & & $\begin{array}{l}14 \text { December: last document dated to } \\
\text { Nebuchadnezzar III. } \\
22 \text { December: first document dated to } \\
\text { Darius. }\end{array}$ & $\begin{array}{l}13 \text { and } 18 \text { December: Darius fights } \\
\text { against Nebuchadnezzar III. Afterwards: } \\
\text { Darius kills Nebuchadnezzar; Persia, } \\
\text { Elam, Media, Assyria, Egypt, Parthia, } \\
\text { Margiana, Sattagydia, and Scythia revolt. } \\
29 \text { December: battle fought in } \\
\text { Arachosia. } \\
31 \text { December: battle fought in Armenia. }\end{array}$ \\
\hline January 521 & & & 12 January: battle fought in Media. \\
\hline February 521 & & & 21 February: battle fought in Arachosia. \\
\hline March 521 & & $\begin{array}{l}\text { March/April: first documents dated to } \\
\text { Nebuchadnezzar IV. }\end{array}$ & 8 March: battle fought in Parthia. \\
\hline April 521 & $\begin{array}{l}5 \text { and } 16 \text { April: documents } \\
\text { dated to Petubastis IV. }\end{array}$ & & \\
\hline May 521 & & & $\begin{array}{l}7 \text { May: Darius fights in Media. } \\
24 \text { May: battle fought in Persia. } \\
21 \text { and } 31 \text { May: battles fought in } \\
\text { Armenia. }\end{array}$ \\
\hline June 521 & & & $\begin{array}{l}11 \text { and } 21 \text { June: battles fought in } \\
\text { Armenia. }\end{array}$ \\
\hline July 521 & & & $\begin{array}{l}12 \text { July: battle fought in Parthia. } \\
16 \text { July: battle fought in Persia. }\end{array}$ \\
\hline August 521 & & $\begin{array}{l}26 \text { August: last document dated to } \\
\text { Darius. }\end{array}$ & \\
\hline \multicolumn{4}{|l|}{ September 521} \\
\hline \multicolumn{4}{|l|}{ October 521} \\
\hline November 521 & & $\begin{array}{l}20 \text { November: last document dated to } \\
\text { Nebuchadnezzar IV. }\end{array}$ & $\begin{array}{l}27 \text { November: defeat and death of } \\
\text { Nebuchadnezzar IV ( } \$ 50 \text {; while Darius } \\
\text { is in Media and Persia). End of Bisitun's } \\
\text { main narrative. }\end{array}$ \\
\hline December 521 & & $\begin{array}{l}6 \text { December: first document dated to } \\
\text { Darius. }\end{array}$ & $\begin{array}{l}28 \text { December: battle fought in } \\
\text { Margiana(?) (\$38). }\end{array}$ \\
\hline \multicolumn{4}{|l|}{ January 520} \\
\hline $\begin{array}{l}\text { January } 520- \\
\text { April } 518\end{array}$ & $\begin{array}{l}\text { March/April: Year } 3 \text { of } \\
\text { Darius in P. Golénischeff (?). }\end{array}$ & & $\begin{array}{l}\text { Darius' second and third years: cam- } \\
\text { paign against Elam; campaign against } \\
\text { Scythia. End of addenda and end of the } \\
\text { Bisitun inscription. }\end{array}$ \\
\hline \multicolumn{4}{|l|}{ May 518} \\
\hline $\begin{array}{l}\text { June } 518 \\
\text { July } 518\end{array}$ & & & \\
\hline
\end{tabular}




\begin{tabular}{ll} 
August 518 & $\begin{array}{l}\text { 31 August: Apis bull dies. } \\
\text { First inscriptions dated to } \\
\text { Darius (Memphis). }\end{array}$ \\
$\begin{array}{l}\text { September } 518 \\
\text { October } 518\end{array}$ & $\begin{array}{l}8 \text { November: Apis bull is bur- } \\
\text { ied. First official inscription } \\
\text { dated to Darius (Memphis) }\end{array}$ \\
$\begin{array}{l}\text { December } 518 \\
\text { January } 517\end{array}$ & $\begin{array}{l}\text { February/March: first } \\
\text { February } 517\end{array}$ \\
& $\begin{array}{l}\text { documents dated to Darius } \\
\text { (Thebes). }\end{array}$ \\
\hline
\end{tabular}

${ }^{a}$ In the case of the Babylonian documents, only the very first and very last documents in which a certain king was recognized are given in Table 1. I have not included the first and last documents of every king per Babylonian city; as noted herein, some cities recognized a king earlier or later than others, and some cities changed hands several times within a short time-span. For regional differences and powerchanges the reader is referred to the lists in Lorenz, Nebukadnezar III/IV, 19-29, and the table in Bloch, "Contribution of Babylonian Tablets": 11-13.

Cambyses' reign in Egypt have left us only a seal and seal impression, ${ }^{14}$ an Apis sarcophagus and epitaph from Memphis, ${ }^{15}$ a sculptural fragment with the beginning of Cambyses' name in paint from the same city, ${ }^{16}$ and several documents from Asyut which were written during his reign. ${ }^{17}$ The four years that followed Cambyses' death are marked by a gap in the Egyptian documentation, which is only broken with several Apis stelae from Memphis that date to the summer of 518 BC (Year 4 of Darius). We therefore have to deal with a miniature "dark age" which happens to cover the exact same years that the Bisitun inscription describes. This may sound suspicious, but a scarcity of dated documents for Late Period Egypt is actually not uncommon. One often finds (series of) undocumented years, either because no (groups of) documents have been found for the period in question, or because archives which span a certain time period display gaps within

${ }^{14}$ Svetlana Hodjache and Oleg Berlev, "Objets royaux du Musée des Beaux-Arts Pouchkine à Moscou," CdE 103 (1977): 37-39.

${ }^{15}$ Georges Posener, La première domination perse en Égypte: recueil d'inscriptions hiéroglyphiques (Cairo, 1936), 30-36.

${ }^{16}$ William M. F. Petrie, The Palace of Apries, Memphis, vol. 2 (London, 1909), 11.

${ }^{17}$ Wilhelm Spiegelberg, Demotische Inschriften und Papyri, Die demotischen Denkmäler 3 (Leipzig, 1932), 39-53; and Arthur F. Shore, "Swapping property at Asyut in the Persian Period," in Pyramid Studies and Other Essays Presented to I.E.S. Edwards, ed. John Baines et al. (London, 1988), 200-206. Later sources sometimes refer back to Cambyses' reign, but I am only concerned with contemporary sources here. the running record. ${ }^{18}$ Such gaps are an obvious problem for any chronological reconstruction, especially when rebel-kings only ruled several months or years before they were defeated. In our case, scholars can insert whatever scenario they prefer into the documentary gap, arguing that either Darius was recognized as the legitimate king in Egypt immediately after Cambyses' death, or that Egypt recognized a native pharaoh up until the summer of 518 BC. We will see later on why the latter scenario may be preferable, based on several Egyptian sources which can be fitted into the documentary gap. But let us first discuss why the former scenario is problematic to start with anyway, and why it is illogical to assume that Egypt would have switched from Cambyses to Darius without any troubling interference.

\section{The Death of Cambyses and Its Consequences in Egypt}

Cambyses' last attested regnal year in both Egypt and Babylonia is Year 8, i.e., 522 BC. The Bisitun inscription

${ }^{18}$ Cf. Mark Depauw, A Chronological Survey of Precisely Dated Demotic and Abnormal Hieratic Sources: Version 1.0 (Trismegistos Online Publications, 2007) for a useful overview of dated documents. The reader is also referred to https://www.trismegistos.org/ calendar/calendar_search.php (accessed May 2018) for the possibility to conduct individual searches of dated documents in Trismegistos. Trismegistos has a near $100 \%$ coverage of the published Demotic sources from Persian Period Egypt, and a ca. 95\% coverage of the published Aramaic sources (see https://www.trismegistos. org/about_coverage.php, accessed May 2018). 
gives no date for his death: it only states that he died "after" Bardiya I took the throne on I July 522 BC, and Cambyses undoubtedly died before Darius killed Bardiya on 29 September 522 вС $(\$ 11-13)$. Interestingly, the last text which is dated to Cambyses' reign comes from Babylonia and is dated 18 April 522 BC (i.e., 23 Nisannu, just after the start of his Babylonian Year 8). Babylonian tablets dated to the reign of Bardiya appear immediately in the following months (from Ayaru, i.e., April/May, onwards). ${ }^{19}$ This creates some tension with the chronological account given by the Bisitun inscription: either Cambyses died prior to I July (contra Bisitun), which would explain why Babylonia switched to Bardiya in April/May; or Babylonia joined Bardiya's revolt while Cambyses was still alive. It also means that either Bardiya took the Persian throne prior to 1 July 522 BC (contra Bisitun), or that his accession on the first of July implies that some kind of official ceremony took place that day, even though he was already recognized as de facto king in the months that preceded it. The latter is a likely scenario; but whether Cambyses was dead or alive while Bardiya was already recognized as king in Babylonia remains uncertain.

To discern what happened in Egypt in those same months, we only have the papyri from Asyut mentioned above. ${ }^{20}$ Two of those papyri were probably written in Cambyses' eighth regnal year, i.e., in $\mathbf{5 2 2}$ BC (P. Cairo 50059; P. BM 10792). It is possible that P. Cairo 50059 mentions Choiak (IV Akhet) as the relevant month, but the reading is uncertain. ${ }^{21}$ If it is Choiak, then this must be April 522 вс (the day is not mentioned). It is the last document dated to Cambyses' reign in the whole of Egypt. This provides an interesting parallel to the Babylonian situation. But as the (absence of) Egyptian documents do not provide us with an alternative king in the following months, it is difficult to attribute any real significance to it. Cambyses, if he were alive after 18 April-and wherever he was - may still have been recognized in Egypt.

\footnotetext{
${ }^{19}$ Yigal Bloch, "The Contribution of Babylonian Tablets in the Collection of David Sofer to the Chronology of the Revolts against Darius I," AF 24/1 (2015): 11.

${ }^{20}$ Of the other sources mentioned, only the Apis epitaph bears a date: it refers to Year 6 of Cambyses (see Posener, La première domination perse, 30-35) and is therefore irrelevant to the present discussion.

${ }^{21}$ Spiegelberg, Demotische Inschriften, 44.
}

If we assume that Egypt recognized Cambyses until his death, then the question remains which king(s) would have been recognized in Egypt after April and/ or July. This question is especially problematic because it is unknown where Cambyses was when he died. As mentioned above, Cambyses was probably in Egypt when the accession troubles began. The Bisitun inscription does not further clarify his whereabouts, but later accounts claimed that Cambyses went back to Iran to deal with Bardiya I- and that he died before he had reached his homeland. Herodotus wrote that he died in "Syrian Ecbatana" (Hist. III 64), and Ctesias that he died in Babylon (Persica FGrH 688 F13).22 This may not sound important to our present discussion, but the location of Cambyses' death would have influenced the speed at which the news of his death reached Egypt. ${ }^{23}$ If Cambyses died after July, far away from the Nile Valley, Egyptians may have only started to consider which king to recognize next in August or September $522 \mathrm{BC}$ - around the time of Darius' murder of Bardiya. But if Cambyses died in April, close to the country from which he had only just departed, Egyptians must have known about his death almost instantly. We are then left with a time period of several months in which Egyptians may have recognized just about anyone before Darius claimed the throne after the end of September. ${ }^{24}$

\footnotetext{
${ }^{22}$ Note that the Demotic Chronicle agrees that Cambyses died "auf dem Weg, bevor er seine Heimat erreichte" (Quack, "Zum Datum der persischen Eroberung Ägyptens": 234), but it does not mention where.

${ }^{23}$ During the time of the Roman Empire, it took fifty-seven days on average for news of an emperor's accession to reach Egypt; see Henry P. Colburn, "Connectivity and Communication in the Achaemenid Empire," JESHO 56 (2013): 48. Communication was probably faster in the Achaemenid Empire (using land routes rather than the Mediterranean Sea), but it is difficult to know how much faster, especially in a time of crisis. The pirradazish service could probably cover the road from Persepolis to Memphis at a maximum speed of twelve days; but, as Colburn notes on analogy with the American Pony Express, trips that took on average thirteen days could take over thirty days if there was hostile interference (ibid., 46). See also Herodotus' comment that heralds were sent out into the provinces to declare the kingship of Smerdis (=Bardiya I), "in particular to Egypt," but that the Egyptian herald found Cambyses and his army in Syrian Ecbatana (Hist. III 61-62; Kuhrt, Persian Empire, 160). This implies that the herald never actually reached Egypt. But it is uncertain what significance we should attribute to the story, not least because we do not know whether an Ecbatana in Syria actually existed (ibid., 162 n. 3).

${ }^{24}$ These are the extreme options, but Cambyses may of course also have died after July but near to Egypt, or after April but far away from Egypt.
} 
Are we to assume that the Egyptians would have known about and approved of the rule of Bardiya, at that time recognized in Babylonia? Or is it more likely that they would have chosen that moment to rebel? If they did recognize Bardiya, are we to assume that they would have switched smoothly from Bardiya to Darius when the latter became king? Or did they choose that moment to rebel, roughly simultaneous with the first Elamite and Babylonian rebellions (see below)? There is no explicit evidence for any of these scenarios. All we know is that the Bisitun inscription does not mention an Egyptian revolt until the end of 522 BC.

\section{Darius' Accession and the Cuneiform Record}

After Darius' accession to the throne, several revolts were waged against his reign. The Bisitun inscription says that Elam and Babylonia were the first to rebel. The Elamite rebel was seized on behalf of Darius, but Darius himself went to Babylonia where he fought two battles on the 13th and 18th of December 522 BC (\$16-19). During his stay in Babylon, Darius claimed, a whole series of revolts broke out against him, and it is here that Egypt is mentioned in the narrative $(\$ 21)$. It remains obscure whether all of these revolts would have occurred at the end of December, or whether some only broke out in January 521 BC and subsequent months. The dates are likely to have varied. Battles were fought in December, January, February, March, May, June, July, October, and November, from northern Assyria and Babylonia to Persia and Parthia (see Table 1). Some campaigns were led by Darius himself, while others were fought on his behalf. Darius' "personal itinerary," so to speak, appears to have proceeded from Media in September 522 BC (to kill Bardiya I: $\$ 13$ ), to Babylonia in December 522 BC (to fight against the rebel Nebuchadnezzar III: $\$ 18)$, to Media again in May 521 вС $(\$ 31-32$; the inscription also mentions several times that armies were waiting for Darius to arrive in Media). Darius is still reported to have been "in Persia and Media" at the time of Babylonia's second revolt, which was thwarted at the end of November 521 BC $(\$ 49-50)$. In other words, there was no time for Darius to go to Egypt in $522 / 52 \mathrm{l} \mathrm{BC}$, and whether he sent someone on his behalf is not mentioned.

The Bisitun narrative gives us Darius' version of events, but the basic reliability of his account and the chaos of his first year of rule are equally clear from
Babylonian texts. ${ }^{25}$ The only thing that the cuneiform record throws some doubt on is the clear-cut chronology outlined by the Bisitun inscription (see Table 1). This has already been noted in the case of Bardiya: we know that Babylonia recognized him from April/May 522 BC onwards, even though Bisitun says that he only claimed the kingship on the lst of July. We also know that some people already recognized Nebuchadnezzar III on the 30th of August, i.e., while Bardiya was still recognized in other parts of the country and about a month before Darius made a bid for the throne. In other words, the first Babylonian rebellion was not specifically waged against Darius, as the Bisitun text would have us believe. But after this point, the dates of the cuneiform documents and the dates given by Bisitun are basically compatible. Bardiya's name disappears from the date formulae after 20 September, which roughly coincides with his death on the 29th, according to Bisitun. The recognition of Nebuchadnezzar spread to other cities from at least the lst of October onwards (Darius was never recognized); and his name disappears after the 14th of December, which roughly coincides with the battles that Darius fought against him on the 13th and 18th of that month. Babylonia subsequently recognized Darius from December 522 BC onwards. But as early as March/April 521 BC, some Babylonian cities already recognized another rebelking, called Nebuchadnezzar IV. The Bisitun inscription does not give a date for the start of this rebellion; it only says that it happened while Darius was still in Persia and Media $(\$ 149)$. As Darius was already in Media on 7 May at the latest (the date of his battle against Fravartish), the inscription and the cuneiform record are at the very least compatible.

In any case, Nebuchadnezzar IV gained widespread recognition in August of $521 \mathrm{BC}$ : the last document dated to Darius stems from 26 August, while the rebel is attested until 20 November. The Bisitun inscription says that he was killed on 27 November, and cuneiform documents are again dated to Darius in early December. That was the end of Darius' troubled first year, and probably when he started thinking about immortalizing the events in an inscription.

It is clear that the Bisitun inscription was not mere rhetoric: the period was one of chaos, battles,

25 The following dates are based on the studies by Jürgen Lorenz, Nebukadnezar III/IV: die politischen Wirren nach dem Tod des Kambyses im Spiegel der Keilschrifttexte (Dresden, 2008), and Bloch, "Contribution of Babylonian Tablets." I have followed Bloch in attributing all tablets dated to "Bardiya" to Bardiya I, not II. 
and different kings being recognized within several months' time (sometimes simultaneously within relatively small regions). One has to wonder how this would have played out for a newly-acquired province on the very western periphery of the empire. Egyptians had ample opportunity to produce their own king and to fight off any Persians who may have been in the country from Cambyses' brief reign onwards.

\section{Petubastis IV}

When scholars first started to discuss the (alleged) Egyptian revolt of the Bisitun crisis, there was no specific Egyptian rebel-king who could be connected to the troubles. This changed in 1972, when Jean Yoyotte re-dated several objects of an otherwise unknown pharaoh to the late sixth century $\mathrm{BC}$. The pharaoh, called Petubastis Seheribre, used to be placed in the Third Intermediate Period, but the objects that bore his name, consisting of a scarab, two seals, three papyri from Meydum, and some fragments of a wooden naos, showed many more affinities with material from the late Saite and early Persian Period. This prompted Yoyotte to connect Petubastis (henceforth "Petubastis IV"26) to the only window of time within that period in which an Egyptian rebel could be expected: the troubled years of Darius' early reign. ${ }^{27}$

The existence of Petubastis IV has been generallyif sometimes tentatively-accepted. To the best of my knowledge, only Marc Rottpeter has seriously rejected the probability of Petubastis' existence in the late sixth century BC. However, he has done so without reference to or any engagement with Yoyotte's study. ${ }^{28}$ The

\footnotetext{
${ }^{26}$ Petubastis Seheribre is often dubbed "Petubastis III." The number changes according to how many kings with the name of Petubastis one thinks existed during the Libyan Period in Egypt. I follow Kaper's numbering here; see Kaper, "Petubastis IV," 125 n. 1.

${ }^{27}$ See Yoyotte, "Pétoubastis." Note that one of the seals with the name of Petubastis was found on one of the papyri, and that another seal was found on them as well: William M. F. Petrie, Ernest Mackay, and Gerald Wainwright, Meydum and Memphis, Memphis, vol. 3 (London, 1910), 43 and pl. XXXVII. This latter seal, however, does not bear the name of Petubastis (nor that of another king), so it is omitted here.

${ }^{28}$ Rottpeter says that "[ü]ber die Herkunft oder die Hintergründe dieses Mannes sind wir aber wiederum völlig im Unklaren, ebenso wie über sämtlicht anderen Details seiner Herrschaft, so diese denn überhaupt und zu diesem Zeitpunkt bestanden hat" (Rottpeter, "Initiatoren," 14). However, Rottpeter's only reference for this is to Werner Huß, Ägypten in hellenistischer Zeit, 332-30 v. Chr. (München, 2001), 35, who gives only a very brief note on the subject in his summary of the 27 th Dynasty. If one wants to
}

similarities between the objects of Petubastis and those of the late Saite and early Persian Period still stand. For example, the two Petubastis-seals are of a specific type (sometimes called "Saite-Persian") characterized by the formula " $s 3+$ name of deity/king + name of official." The divine names that are mentioned on this type of seal vary, but the royal names are remarkably homogenous: the mentioned king is always Amasis, the last long-reigning king of the Saite dynasty — with the only exceptions being the two seals that mention Petubastis IV. The striking stylistic similarity indicates that Petubastis should be placed close to the reign of Amasis rather than centuries before it. The publication of new seals of this kind after 1972 has only strengthened this impression. ${ }^{29}$ For other arguments that place the objects of Petubastis IV in the late sixth century $\mathrm{BC}$, I refer the reader to Yoyotte's article.

Significantly, recent excavations in the Dakhla Oasis have turned up even more sources for Petubastis' reign: several temple blocks were uncovered at Amheida in 2014 that bear cartouches of Petubastis and some elaborate titles. The finds further corroborate a Saite/Persian date: while Petubastis' titulary resembles those of the Saite kings, the small size of the cartouches and the confusion of the signs $p r$ and $h$ also occur in some inscriptions of Darius I at nearby Hibis. ${ }^{30}$ Taken together with the earlier material of his reign, it becomes quite inescapable to place Petubastis somewhere between the periods of rule by Amasis and Darius - and therefore to connect him with the Bisitun crisis. Note also that the new finds extend the recognition of Petubastis all the way down to the Southern Oasis (i.e., his rule was not just confined to the north, as some have claimed), and that this king apparently had enough time and power to start

throw doubt on Petubastis's existence during the Bisitun crisis, it is imperative to engage with the study by Yoyotte.

${ }^{29}$ This type of seal was first recognized by Herman De Meulenaere, who mentions five seals with the name of Amasis and one with the name of Petubastis ("Trois Empreintes de Sceaux," CdE 39 [1964]: 29-30). Yoyotte mentions nine examples with the name of Amasis ("Pétoubastis": 219-20). For examples of and further references to this type of seal with the name of a deity, see JeanPierre Corteggiani, "Documents divers (I-VI)," BIFAO 73 (1973): 151-53, pl. XIII; and Alain-Pierre Zivie, "Une empreinte de sceau d'époque saite," RdE 30 (1978): 175-77, which might be an example of a deified Apries(?), not in cartouche. The most recent addition to the corpus known to me is a seal found in the priests' quarter of Karnak which likewise mentions Amasis (Aurélia Masson, "Un scellé du vizir Psametik-mery-neith,” CdK 12 [2007]: 657-58).

${ }^{30}$ Kaper, "Petubastis IV," 128-38. 
an actual building project there. In other words, it is highly probable that Petubastis was the (or one of the) Egyptian rebel-kings of the Bisitun crisis; and, to judge by the source material he left behind, he was not so swiftly defeated. It remains to be seen just exactly how long he ruled.

\section{The Meydum Papyri}

The only dated documents that can be connected to the reign of Petubastis are three fragmentary papyri which were found in the rubbish of the Meydum pyramid. ${ }^{31}$ They are letters and seem to deal with issues of land in the nome of Herakleopolis. The date of one of them cannot be properly read, but the dates of the others are the 6th and 17th day of Choiak (IV Akhet), Year 1 . Year 1 of which king is not stated (a common phenomenon in letters), but the paleography of the papyri indicates a date in the early Persian Period. ${ }^{32}$ Therefore, Year 1 could theoretically be connected to Cambyses, but this is unlikely because he only conquered Egypt in his third regnal year; to Darius I, which is also unlikely as the papyri would then date to April of $521 \mathrm{BC}$, meaning that Darius would have quelled the Egyptian rebellion almost immediately after it had started and yet did not incorporate a record of its defeat into the Bisitun inscription; or to Petubastis IV. That the latter is the most likely option is borne out by a seal impression on one of the papyri: it is of the specific Saite-Persian type mentioned above, and it shows the feathered cartouche of Petubastis' prenomen, Seheribre. It is therefore safe to date the documents to Year 1 of that king. ${ }^{33}$

${ }^{31}$ Petrie, Mackay, and Wainwright, Meydum and Memphis, 43 and pl. XXXVII; Yoyotte, "Pétoubastis": 217 n. 3. For editions of the papyri see Eugene Cruz-Uribe, "Early Demotic Texts from Heracleopolis," in Res severa verum gaudium: Festschrift für KarlTheodor Zauzich zum 65. Geburtstag am 8. Juni 2004, ed. Friedhelm Hoffmann and Heinz J. Thissen (Leuven, 2004), 59-66; and (with several corrected readings) Günter Vittmann "Two Administrative Letters from Meidum (P. Ashmolean 1984.87 and 1984.89)," in Mélanges offerts à Ola el-Aguizy, ed. Fayza Haikal (Cairo, 2015).

32 Cruz-Uribe, "Early Demotic Texts," 59-60.

${ }^{33}$ Already assumed by Yoyotte, "Pétoubastis," Cruz-Uribe, "Early Demotic Texts," and Vittmann, "Administrative Letters." Seals could be used for generations, so the occurrence of a seal with a king's name does not necessarily mean that the relevant document also dates to that king's reign; see for example the use of two seals with the name of Darius on tablets dated to Xerxes (Mark B. Garrison "The Royal-Name Seals of Darius I," in Extraction and Control: Studies in Honor of Matthew W. Stolper, ed. Michael Kozuh, et al. [Chicago, 2014], 77-81). But as a seal with the name of a
Based on the date in the documents, there are three mutually exclusive chronological options to consider. The first option is that Bardiya I may have rebelled on 11 March 522 вс. Cambyses would have left Egypt for Iran to deal with the troubles, and some Egyptians immediately took the opportunity to revolt against the Persian king and establish Petubastis as pharaoh instead. Petubastis' reign was recognised as Year 1 according to traditional Egyptian custom, and the Meydum papyri therefore refer to the 6th and 17th of April $522 \mathrm{BC}-$ i.e., only very shortly after the accession of Petubastis, and while Cambyses was still recognized in Babylonia. The possible reading of Choiak, Year 8 of Cambyses, in the document from Asyut (P. Cairo 50059) must then refer to an earlier day in April, or is evidence for different parties in Egypt recognizing different kings (as sometimes happened in Babylonia; see above). Under the terms of this option, the chronological picture of the Bisitun inscription (i.e., that Egypt only revolted at the end of $522 \mathrm{BC}$ ) should be discarded.

The second option is that the chronology of the Bisitun inscription is roughly reliable and Egypt therefore revolted at the turn of 522/521 BC. Petubastis ascended the throne at some point between 1 Thot and the beginning of Choiak, i.e., between 1 January and 31 March $521 \mathrm{BC}$, and the Meydum documents therefore refer to 5 and 16 April of that year specifically. Year 8 of Cambyses in the Asyut documents can thus refer to any date in $522 \mathrm{BC}$, and it remains unknown, under the terms of this option, whom Egypt may have recognized from Bardiya's revolt and Cambyses' death onwards.

The third and final option is that Egyptians may have rebelled either around the time of the departure and death of Cambyses, or at the end of 522/521 BC, but that the rebel-king who was recognized was not Petubastis IV (see the multiple rebel-kings in Babylonia for a parallel case). It was only later that Petubastis claimed the Egyptian throne, and the Meydum documents may therefore refer to any Choiak between 520 and 518 BC.

The first option is theoretically possible and quite tempting to adopt, as it provides us with a fascinating historical narrative of revolt, death, swift accession, and different political parties in Egypt within a short

rebel-king is unlikely to have been used after that king's defeat by the Persians, dating the letters to Petubastis IV remains the most likely option. 
period of time. ${ }^{34}$ But it also entails some large assumptions. For example, we would have to assume that it is indeed "Choiak" - and not a later month - that is mentioned in P. Cairo 50059, and that this solitary text really was the last document dated to Cambyses' reign, instead of merely the only document preserved for Cambyses' last year in Egypt; or we are forced to assume that both Cambyses and Petubastis were recognized simultaneously in Egypt. Additionally, either of these scenarios requires us to discard the Bisitun chronology, which, as seen above in the case of Babylonia, is roughly reliable. The second and third options are therefore preferable to the first.

The third option may seem unlikely at first sight but is quite possible: there are three Egyptian objects of otherwise unknown kings who may have been rebelkings of the Persian Period. These are a sistrum-handle and a statue of a certain Psamtik Amasis, and a scarab dated to Psamtik Nebkaenra. ${ }^{35}$ These objects may have belonged to later rebel-kings, but they could also stem from unknown rebels of the Bisitun crisis.

The second option, however, is the most likely one: the Amheida excavations have clarified the extent of the power of Petubastis, and that he had enough time and resources to start an actual building project. It is therefore better to place his recognition as pharaoh of Egypt earlier rather than later - and the most likely conclusion is thus that (some) Egyptians rebelled at the turn of $522 / 521 \mathrm{BC}$, and that Petubastis was recognized as pharaoh, at least in the nome of Herakleopolis, in the early months of 521 вС. $^{36}$

\section{The End Point of the Revolt and the Silence of the Bisitun Inscription}

The three papyri from Meydum are unfortunately an isolated find. They are not part of any known, larger archive, and they give us no clue as to what happened after April 521 BC. But it is clear from the Bisitun inscription that Darius was busy fighting off revolts until the very end of that year. Did he subdue Egypt's revolt in those months as well?

\footnotetext{
${ }^{34}$ It is also possible that people in Asyut still dated their documents to Cambyses because the news of his death reached them later than the more northern Herakleopolis.

${ }^{35}$ Kienitz, Die politische Geschichte, 233.

${ }^{36}$ Note that this does leave room for either of the two Psamtiks to have ruled prior to Petubastis IV, as the king recognized in Egypt after April 522 BC remains a mystery.
}

Possibly: after all, Darius did claim that he did many more things than the Bisitun inscription recorded, but that he had not included all of them lest future generations would not believe him $(\$ 58)$. In theory, then, he (or more realistically: someone on his behalf) could have subdued Egypt in 521 вC. Some scholars have attributed this role to Aryandes, the satrap of Egypt from Cambyses' reign onwards. ${ }^{37}$ We have no Egyptian sources for Aryandes, however; we do not know where he was when Cambyses died (did he stay in Egypt or accompany his king to the crisis in the heartland?) or when Darius became king; nor do we know on how many Persian troops he could have relied in $522 / 521$ BC. As we know that later Egyptian rebellions had to be subdued with imperial reinforcements (in other words: the troops stationed in Egypt were not enough to deal with these crises), I think it very unlikely that Aryandes succeeded without such help. ${ }^{38}$ However, the idea that Darius could have sent imperial reinforcements in 521 вC sounds equally unlikely: Bisitun mentions armies occupied with battles in almost every month of $521 \mathrm{BC}$, and we cannot assume that the military power of this new king was endless. On top of that, the inundation season in Egypt would have made a military campaign difficult for a large part of the year (from about July through October), as most of the Nile Valley would have been flooded. ${ }^{39}$ It is therefore more probable that Darius (or someone on his behalf with imperial reinforcements) subdued Egypt at some point after 521 BC, which would also explain Egypt's absence in the main narrative of the Bisitun text. By January 520 BC, Darius had been sitting on the throne for over a year, killed off most rebellions, and secured his position in the heartland of the Persian Empire. According to this understanding, he ordered a monumental inscription to be written, recording all of his exploits from his troubled first year, and only then

\footnotetext{
${ }^{37}$ E.g., Briant, Cyrus to Alexander, 115. For more on Aryandes, see below.

${ }^{38}$ According to the Greek sources, external armies had to be sent against Egypt to subdue both the second and the third revolt (Herodotus Hist. VII 1, 5, 7; Thucydides, History of the Peloponnesian War I 104, 109-110); the fourth revolt was successful, and Egypt was only reconquered after several Persian military attempts. For the unpublished statue, see Karl Jansen-Winkeln, Inschriften der Spätzeit, Teil IV: Die 26. Dynastie. Band 1, Psametik I.-Psametik III (Wiesbaden, 2014), 584-85.

${ }^{39}$ For the difficulty of invading Egypt, see Dan'el Kahn and Oded Tammuz, "Egypt is difficult to enter: Invading Egypt-A Game Plan (seventh — fourth centuries BCE)," JSSEA 35 (2008): esp. 43 and 50 on the inundation season.
} 
turned his head towards Egypt - a country on the very western periphery of his empire and one which, we should remind ourselves, had only been part of the empire for about four years.

But the problem then is this: why did Darius not record his defeat of Egypt in the addenda to the Bisitun inscription? The addenda were inscribed after the entire relief had already been created, and these extra portions of text record campaigns of Darius in his second and third years of rule. According to the text, Elam rebelled (again) and was defeated on behalf of Darius; while Darius himself (apparently at some later point in time) conducted a campaign against the Scythians $(\$ 71) . .^{40}$ If Darius had also sent or led a campaign against Egypt in the meantime, why do the addenda not mention it? Would Egypt have been that unimportant to Darius? I find that hard to believe. Darius' later building in Egypt and his Egypto-Persian monuments show a specific interest in the Two Lands. ${ }^{41}$ The silence of the addenda therefore gives the impression that Egypt was still not subdued in the third year of Darius' reign; and that Petubastis may have continued to wield his scepter there.

It is unfortunately unclear when Darius would have had the addenda inscribed, or indeed what the exact dates of the Elamite and Scythian campaigns were. It is possible that one was conducted in his second year and the other in his third, but the inscription as preserved does not specifically claim this. Both campaigns could have started in his second year while the Scythian campaign (which was at least conducted after the Elamite campaign) ended in Darius' third year. If we assume that Darius' "third year" refers to his third (Babylonian) regnal year, then this must refer to some point between 1 Nisannu 519 BC (23 March) and l Nisannu 518 вС (11 April). If, on the other hand, his "third year" refers to his third year from the date of his accession to the throne (which might be more likely, as he earlier referred to the events of his accession year and the first part of his first regnal year as his "first year"), then it must refer to the period between November/December $520 \mathrm{BC}$ and November/De-

${ }^{40}$ The text is only recorded in Old Persian and is "much damaged by weathering from water and ice" (Bae, Comparative Studies, 221).

${ }^{41}$ See Melanie Wasmuth, "Political Memory in the Achaemenid Empire: The Integration of Egyptian Kingship into Persian Royal Display," in Political Memory in and after the Persian Empire, ed. Jason Silverman and Caroline Waerzeggers (Atlanta, 2015). cember 519 вс. ${ }^{42}$ This problem cannot be adequately resolved, though it matters a lot for the chronology of Petubastis' reign.

Let us look at two important options. On the one hand, if the "third year" in the Bisitun addenda refers to Darius' third (Babylonian) regnal year, then the addenda must have been inscribed at some point after 23 March 519 BC (the start of that same regnal year). Darius may still have been fighting against the Scythians in the early part of Year 3; and the inundation season will have made it difficult to conquer Egypt in the ensuing months (roughly July through October). A campaign against Egypt is therefore most likely to have happened in the midst of his third regnal yeari.e., at the end of $519 \mathrm{BC}$-or even later.

On the other hand, if the "third year" refers to Darius' third year from the date of his accession to the throne, then the addenda must have been inscribed at some point after November/December 520 BC, about two years after his probable accession to the throne. Darius may still have been fighting against the Scythians in the early part of his third year, but he could have campaigned against Egypt at any time after that-i.e., in early 519 вС or later.

Note that even if the additions were inscribed at the start of 519 вС (i.e., directly after the end of the Scythian campaign, if we assume that this campaign ended early in Darius' third year from his accession onwards), this does not dictate that Darius waged a successful military campaign against Egypt shortly thereafter. The specific date for the Egyptian campaign completely depends on how one interprets later sources for Darius' reign in Egypt.

\section{Darius' “Third Year" in Egypt}

I claimed above that Darius' first attested regnal year in Egypt is Year $4(518 \mathrm{BC})$. This terminus ante quem

\footnotetext{
${ }^{42}$ Parker considers it a fact that Year 2 and 3 do not refer to regnal years but to "year-periods" from Darius' accession to the throne ("Darius and his Egyptian Campaign": 374 n. 9). Note that the exact date of his accession is unknown: the Bisitun inscription only says that Darius became king "after" he had killed Bardiya on 29 September $(\$ 13)$. But, as it is likely that his "first year" includes the first dated battle (against Nebuchadnezzar III in Babylonia, 13 December $522 \mathrm{BC}$ ) and the last dated battle (against Frada in Margiana, 10 December 521 BC), we should probably place Darius' accession to November or early December (note the more than three months between Bardiya's rebellion in March and his seizure of the kingship in July 522 BC). See Depuydt, "Evidence for Accession Dating": 196-97.
} 
for the end of Petubastis' revolt does not help us answer the question whether Darius defeated Egypt in 519 BC or a year later in 518 BC. But two sources have often been used to argue in favor of the former date. These include first a document which is allegedly dated to Darius' third regnal year in Egypt and, second, the mention of a "Year 3" of Darius in a Ptolemaic Demotic text. However, the reading of "Year 3" of Darius in these documents is problematic; and they cannot, in my view, be used to argue for his recognition in Egypt at that time.

The first document is a fragmentary Demotic papyrus called P. Golénischeff, which has never been properly published, although Eugène Revillout did attempt a preliminary hand-copy and translation of the papyrus in $1883 .{ }^{43}$ Years later, Francis Griffith added a description of the fragments on the basis of photographs and presented his own (brief) interpretation of the papyrus. He thought that there "appear to be remains of eight columns, and more may have existed originally." ${ }^{44}$ The second of these columns contains a reference to Year 3 of Darius, specifically the months of Phaophi and Choiak of that year. ${ }^{45}$ Griffith thought the column might concern "[g]old and silver left in the temple" of Edfu in year 3 of Darius, which the priests subsequently divided amongst themselves. ${ }^{46}$ This has prompted some scholars to date the entire papyrus to Year 3 of Darius, ${ }^{47}$ but it is unclear whether it actually does. It is equally possible that the papyrus was written later in Darius' reign and that it happens to mention Year 3 in an account of things done at

${ }^{43}$ Eugène Revillout, "Seconde lettre de $M$. Revillout à $M$. Lenormant de l'institut sur les monnaies égyptiennes," RE $3 / 2$ (1883): 62-63 and pl. 1-2.

${ }^{44}$ Francis Ll. Griffith, The Demotic Papyri in the John Rylands Library Manchester: Key-List, Translations, Commentaries and Indices (Manchester, 1909), 25.

${ }^{45}$ Revillout translates the first line as "Ceux qu'on a établis dans le sanctuaire de Hor-merti en l'an 43 du roi Darius, toujours vivant, paophi" (Revillout, "Seconde lettre": 63). The published Year "43" is presumably a mistake for " 3 ," since Revillout translates "An 3, Choiak" (without the name of a king, but presumably still Darius) later in the same column. Griffith does not give a translation of his own.

${ }^{46}$ Griffith, Demotic Papyri, 25.

${ }^{47}$ For the idea that the document dates to Year 3, see e.g., Didier Devauchelle, "Un problème de chronologie sous Cambyse," Transeuphratène 15 (1998): 15; Eugene Cruz-Uribe, "The Invasion of Egypt by Cambyses," Transeuphratène 25 (2003): 54-55; Quack, "Zum Datum der persischen Eroberung Ägyptens Ägyptens": 241 n. 62. Devauchelle suggests it to be Darius II, but CruzUribe thinks it is paleographically more likely to date to Darius I. the temple in previous years. If the latter were the case, the document could not serve as direct proof for Darius' control of Egypt in his third year: the Egyptian priests may have simply attributed that year to him when writing at a later time, ignoring the by-then defeated revolt. This was also done in contemporary Babylonia, where some accounts which had to refer back to the period of the Babylonian revolts against Darius simply ignored those rebel-kings and dated the period by "the first year of Darius" instead. ${ }^{48}$ In short, P. Golénischeff cannot be used to argue for Darius' uncontested dominion over Egypt in his third regnal year.

The second document of concern to us is the Demotic Chronicle from the Ptolemaic Period. ${ }^{49}$ Its contents are mainly literary in nature, with a series of oracles on the front, and on the back a tale about Amasis, some short passages which have to do with priestly affairs, and possibly animal fables. ${ }^{50}$ The paragraphs about priestly affairs contain the infamous paragraph about Cambyses' restrictions on the Egyptian temples. But the paragraph relevant to the present discussion is Darius' order to his satrap to collect the laws of Egypt. The Demotic text says that the order was sent in a specific year, and the argument goes that this year must be a terminus ante quem for Darius' conquest of Egypt. After all, Darius could not have had the laws of Egypt collected by his satrap if Egypt was still in revolt. Unfortunately, though, the correct reading of the regnal-year number which is given in the Demotic text is disputed. Spiegelberg, in his original publication of the papyrus, reads "Year $3 . " 51$ The reading of

\footnotetext{
${ }^{48}$ Caroline Waerzeggers, "The Silver Has Gone ... Temple Theft and a Divided Community in Achaemenid Babylonia," in Silver, Money and Credit: A Tribute to Robartus J. Van der Spek on the Occasion of his 65th Birthday, ed. Kristin Kleber and Reinhard Pirngruber (Leiden, 2016), 83-84. Parker already considered the possibility of retroactive dating in P. Golénischeff in 1941 (Parker, "Darius and his Egyptian Campaign": 375-76). A similar phenomenon might be visible in the small archive of Asyut priests mentioned above: see Quack, “Zum Datum der persischen Eroberung Ägyptens": 242.

${ }^{49}$ Its paleography indicates a date in "the later half of the third century [BC]" (Kuhrt, Persian Empire, 126 n. 1).

${ }^{50}$ Wilhelm Spiegelberg, Die Sogenannte Demotische Chronik: des Pap. 215 der Bibliothèque nationale zu Paris nebst den auf der Rückseite des Papyrus stehenden Texten (Leipzig, 1914). The whole papyrus is very hard to read; whether the last paragraphs indeed contain animal fables is uncertain (ibid., 34).

${ }^{51}$ Not "Year 4," as Tuplin implies (Tuplin, "Darius' Suez Canal," 265; cf. Spiegelberg, Demotische Chronik, 30-31).
} 
"Year 3" has subsequently been followed, ${ }^{52}$ but some have given the number as "Year 4" instead..$^{53}$ Quack has recently reiterated the reading of "Year 3 " on the basis of photographs, rejecting the translation of "Year 4" ("ohne weiteren Kommentar") given by CruzUribe. ${ }^{54}$ Parker, however, already translated "Year 4" in 1941. As Parker notes, it is evident from Spiegelberg's glossary that Spiegelberg himself also identified the relevant sign as " 4 ," and not " 3 ," but that he had apparently "failed to correct the translation." ${ }^{55}$ As I am not a demotist, I will refrain from joining the discussion on translation. Suffice it to say that either reading is insufficient as terminus ante quem for Darius' conquest of Egypt: we should be very careful with a document that was written two to three centuries after the events it claims to describe.

The difficulties of translation, possible retroactive dating, and historical inaccuracy centuries after the fact are one thing. But there is also a more fundamental issue at stake, which has not been noted before: this is that "Year 3" in either case has been taken to refer to the Egyptian dating system and is interpreted as if Darius enjoyed a smooth succession in Egypt. If we imagine that Darius suffered no troubles of recognition in the Two Lands, then he had to have had an accession year in Egypt (according to the EgyptianPersian way of dating established under Cambyses), and he must have enjoyed a Year 1 from 1 Thot onwards (1 January $521 \mathrm{BC}$ ). Year 3 would then refer to the period of 31 December 520 вс to 30 December 519 BC. But, as shown above, Darius enjoyed an extensive crisis of legitimacy in his first year of rule. It is also uncertain if Darius already conquered Egypt in 519 BC or a year later. If we assume that Darius conquered Egypt at the start of $519 \mathrm{BC}$, then he was in his second regnal year at that time according to the Baby-

\footnotetext{
${ }^{52}$ E.g., Didier Devauchelle, "Le sentiment anti-perse chez les anciens Égyptiens," Transeuphratène 9 (1995): 74; Kuhrt, Persian Empire, 125; Damien Agut-Labordère, "Darius législateur et les sages de l'Égypte: un addendum au Livre des Ordonnances," in Élites et pouvoir en Égypte ancienne, ed. Juan C. Moreno García (Lille, 2009/2010), 355.

${ }^{53}$ Tuplin, "Darius' Suez Canal," 265; Cruz-Uribe, "Invasion of Egypt”: 47.

${ }^{54}$ Quack, "Zum Datum der persischen Eroberung Ägyptens": 235 n. 31.

${ }^{55}$ Parker, "Darius and his Egyptian Campaign": 373 n. 1; cf. Spiegelberg, Demotische Chronik, 144. However, Quack has rightly pointed out to me that it could have been the other way around: that Spiegelberg may have read "4" initially, and changed his mind to " 3 " at a later stage (pers. comm., February 2018).
}

lonian system of dating. We then have to face the same questions as for Cambyses' conquest of Egypt: when would Egypt have switched to its own dating system? Would it have adopted Year 2 at the start of 519 BC, or would it immediately have referred to Year 3 in a "preemptive strike" against the dating problem? If the former, then when would Egypt have switched to Year 3 instead? Probably at 1 Nisannu, together with the Babylonians. ${ }^{56}$ Year 3 of Darius in Egypt would then have lasted from 23 March until 31 December 519 BC, after which Egypt switched to year 4. But if Darius conquered Egypt at the start of 518 BC, in his third regnal year according to the Babylonian system, then Year 3 in Egypt could refer to the early months of 518 вС until 1 Nisannu (11 April), after which it would have switched to year 4 . Neither P. Golénischeff nor the Demotic Chronicle help us solve this problem.

Let us look into this problem in a bit more detail. We can assume that P. Golénischeff was written in the reign of Darius I, but in an unknown year. The dates given in the fragmentary text, according to Revillout, are Mecheir (II Peret) in column one, year " 43 " (sic) of Darius in column two, and "Year 3 Choiak" a little later in the same column. ${ }^{57}$ Mecheir is the second month after Choiak, so whatever was recorded in column one seems to have concerned an earlier year than "Year 3" in the second column. However, we do not know to which year or which king it would have referred, as the text is very fragmentary at that point. Choiak, on the other hand, gives us several possible dates:

1. If "Year 3 Choiak" refers to the third year of Darius according to the Egyptian dating system, then this must be 31 March-29 April 519 BC. This is either:

la. a "real" date and indicative of Darius' conquest of Egypt prior to 31 December (1 Thot) 520 BC, i.e., in Darius' second (Babylonian/Egyptian) regnal year.

\footnotetext{
${ }^{56}$ As in the case of Cambyses, Egypt could also have skipped the Babylonian New Year and continued to date to Year 2 after Nisannu (Quack, “Zum Datum der persischen Eroberung Ägyptens”: 243). They would then have had to amend the situation on the following 1 Thot, by adding two regnal years instead of one. This strikes me as the least likely option, especially because the problems of timekeeping would already have been known in Egypt from Cambyses' reign. It would have been easiest to switch to the next year on 1 Nisannu, together with the Babylonians, until the next 1 Thot occurred, and time-keeping could again be done according to the Egyptian calendar.

${ }^{57}$ Revillout, "Seconde lettre": 62-63. Griffith does not mention the months, only the third year of Darius in column 2 (Griffith, Demotic Papyri, 25).
} 
This is unlikely in view of the Bisitun addenda, which can only have been inscribed after December 520 BC at the earliest (see above); or

lb. part of retroactive dating as suggested above, which does not tell us anything about the actual conquest of Egypt.

2. If "Year 3 Choiak" refers to the third year of Darius according to the Babylonian dating system, then this date must fall between 23 March (1 Nisannu) 519 BC and 11 April (1 Nisannu) 518 BC. Choiak then refers to either:

2a. 31 March-29 April 519 вС (identical to the date of option 1 above), which implies that Darius' conquest of Egypt was only completed after 31 December 520 BC (1 Thot) and before 31 March-29 April 519 BC, which is a bit better in view of the Bisitun addenda, but still creates some tension; ${ }^{58}$ or

2b. 31 March-29 April 518 BC. 1 Nisannu fell on 11 April that year, so depending on the day of the month (which is not recorded), the document could refer to a day shortly before Nisannu, when both the Babylonians and the Egyptians would have switched to year 4 of Darius. This would set the parameters for Darius' conquest of Egypt between 31 December 519 BC (1 Thot) and 31 March-29 April 518 BC (Choiak).

Options $\mathrm{la}$ and $2 \mathrm{a}$ are not so easily reconciled with the date of the Bisitun addenda; these options are only likely if we posit that Darius did not include Egypt's defeat in the inscription, even though he could have. I have rejected this position above based on Darius' evident interest in the Two Lands. Options $1 \mathrm{~b}$ and $2 \mathrm{~b}$ are therefore the more likely ones.

The same reasoning applies to the Demotic Chronicle: the text could refer to any period between 31 December 520 BC-31 December 519 BC (the Egyptian Year 3, assuming a smooth succession), 23 March 519 BC-11 April 518 BC (the Babylonian Year 3, assuming a conquest of Egypt in Darius' third Babylonian regnal year), or 31 December 519 BC-31 December $518 \mathrm{BC}$ (the Egyptian Year 4). As there is no way of

\footnotetext{
${ }^{58}$ As for the difference between options $1 \mathrm{a}$ and $2 \mathrm{a}$ : the point is that if Darius conquered Egypt prior to 31 December 520 BC, "Year 3" would refer to a year that had started on the Egyptian New Year and would therefore be distinctly "Egyptian;" whereas Darius' conquest of Egypt after 31 December 520 BC in his Babylonian Year 2 means that Egyptians would have had to switch to Year 3 either "preemptively" or together with the Babylonians on 23 March that year (1 Nisannu).
}

deciding which date the author of this late, Ptolemaic text actually had in mind, the best terminus ante quem for the defeat of Petubastis remains August 518 BC (see below). ${ }^{59}$

\section{The Recognition of Darius in Egypt}

The earliest certain and contemporary references to Darius' kingship in Egypt are given by a series of stelae which recount the burial of an Apis bull in Memphis. The date of its death is given as Pakhons (I Shemou), day 4, Year 4 of Darius (=31 August 418 BC), while the burial of the bull is dated to Epeiph (III Shemou), day 13, Year 4 of Darius ( $=8$ November 518 вC). ${ }^{60}$ These are the only contemporary attestations we have for Darius' fourth year in Egypt. The earliest documentation thereafter consists of four Theban papyri dated to Hathyr (III Akhet) of Darius' fifth year, i.e., 29 February-29 March 517 вс. ${ }^{61}$ In other words, Darius was recognized as pharaoh at the latest in August 518 $\mathrm{BC}$ in Memphis and in February/March 517 BC in the southern city of Thebes. Although these sources provide a secure end-point for Petubastis' reign, Darius' campaign could still have happened in either 519 BC or 518 вс.

\section{Polyaenus and the Apis Burial of 518 вС}

That Darius re-conquered Egypt in 518 BC is only a possibility, but it has been the preferred date for some scholars. This is mainly due to a passage in the

\footnotetext{
${ }^{59}$ As both a reading of Year 3 and Year 4 in the Demotic Chronicle could refer to the year of Darius' conquest of Egypt, the order to collect the laws of Egypt may in either case be a euphemistic reference to Darius' reconquest of the country and the start of a new era of Persian rule.

${ }^{60}$ For references to the Apis stelae made by non-royal persons, between the Apis' death and its burial, see Didier Devauchelle, "Les stèles du Sérapéum de Memphis conservées au musée du Louvre," EVO 17 (1994): 103. For the official epitaph, see Posener, La première domination perse, 36-41. It has often been noted that Darius does not bear an Egyptian throne name in the Apis inscriptions, which might indicate that it had not been composed yet at that time-something that would be possible if Darius had only just reconquered the country (ibid., 176; Tuplin, "Darius' Suez Canal," $265)$. However, Parker was right to shed some doubt on the significance of this name's absence, as Darius' later monuments in Egypt almost never mention it either (Parker, "Darius and his Egyptian Campaign": 376).

${ }^{61}$ See Pieter W. Pestman, Les papyrus démotiques de Tsenhor ( $P$. Tsenhor): les archives privées d'une femme égyptienne du temps de Darius Ier, vol. 1 (Leuven, 1994), 46-59 and 60-62.
} 
Stratagems, a second century AD work by Polyaenus. Polyaenus provides his reader with a collection of military exempla, both from the Greco-Roman and the "barbarian" world. In one of those exempla, he describes how Darius responded to an Egyptian revolt. The Egyptians, according to Polyaenus, had revolted because of the cruelty of their satrap Aryandes. Darius subsequently marched towards Egypt to deal with the troubles, but when he arrived in Memphis he found the Egyptians commemorating the death of an Apis bull. Cleverly, the Persian king promised to give a hundred talents of gold to the man who could produce a new Apis. This gesture impressed the Egyptians so much that they voluntarily subdued the rebels and gave all of their support to Darius instead (Polyaenus Stratagems VII 11).

Polyaenus gives no date for the event, but the connection of the revolt with Aryandes gives us an approximate time span. Aryandes was probably the satrap of Egypt from Cambyses' conquest until some point in Darius' reign. We mainly know this from Herodotus: he says that Cambyses appointed Aryandes (Hist. IV 166); he mentions Aryandes' role in a Libyan campaign, which was roughly contemporaneous with Darius' campaign against the (European) Scythians (Hist. IV 165, 167, 200-205); he eventually describes how Aryandes was executed by Darius on the charge of rebellion (Hist. IV 166). When Aryandes was allegedly executed is not mentioned, but other passages in Herodotus indicate that it must have happened after ca. 515 BC. ${ }^{62}$ Egyptian sources complement this picture to some extent: we have no secure references to Aryandes in Egyptian sources, but we do know that a certain Pherendates was satrap of Egypt from at least 492 BC onwards. ${ }^{63}$ This means that Aryandes must

${ }^{62}$ According to Herodotus, Aryandes was still the satrap of Egypt during the Libyan campaign. This campaign was synchronized with Megabazos' operations in the Hellespont following Darius' (European) Scythian campaign (Hist. IV 145). As the latter can be dated to somewhere between 515-513 BC (János Harmatta, “Darius' Expedition against the Saka Tigraxauda," Acta Antiqua 24 [1976]: 17), the Libyan campaign must have happened around the same time (Barbara M. Mitchell, "Cyrene and Persia," JHS 86 [1966]: 101).

${ }^{63} \mathrm{He}$ is mentioned in several Demotic letters from Elephantine; see Cary J. Martin, "Demotic Texts," in The Elephantine Papyri in English: Three Millennia of Cross-Cultural Continuity and Change, ed. Bezalel Porten (Leiden, 1996), 289-97. Note that a certain Parindadda in two texts from the Persepolis Fortification Archive (NN 1271 and NN 2472) may be the same man as Egypt's Pherendates; see Wouter F. M. Henkelman's “Anhang: Egyptians in the have lost his position between ca. 515 and 492 BC, and that the story in Polyaenus can only be connected to an Apis burial pre-dating 492 BC (Year 30 of Darius).

It is presently known that there were four Apis bulls between the end of the reign of Amasis and the end of that of Darius: one Apis bull was probably born in Year 27 of Amasis and died in year 6 of Cambyses; the second died in year 4 of Darius; the third in Year 31 of Darius; and the fourth in Year 34. There is hardly any evidence for Persian Period Apis bulls after that date, but that is of no concern to us now. What matters is that the only bull who could have died during Darius' reign and during Aryandes' term of office is the Apis that died in Year 4 of Darius: ${ }^{64}$ those of Year 31 and Year 34 fall within Pherendates' period. So if we want to take Polyaenus seriously, then his passage must indeed be connected to $518 \mathrm{BC}$, and understood to refer to an Egyptian rebellion in Darius' first four years of rule. This would explain why the defeat of such a revolt is not mentioned in the Bisitun inscription, and also why the first contemporary evidence for Darius' recognition in Egypt is related to an Apis burial. In other words, the Polyaenus story is pretty much a perfect fit for the Petubastis revolt. ${ }^{65}$

Persepolis Archives," in Ägypto-persische Herrscher-und Herrschaftsprösentation in der Achämenidenzeit, ed. Melanie Wasmuth (Stuttgart, 2017), 294; and "Imperial Signature and Imperial Paradigm: Achaemenid administrative structure and system across and beyond the Iranian plateau," in Administration in the Achaemenid Empire, ed. Bruno Jacobs, Wouter F. M. Henkelman, and Matthew W. Stolper (Wiesbaden, 2017), 78. NN 2472 is a travel authorization by Parindadda dated to the first month of Year 27 of Darius I, which may indicate that Pherendates was already satrap in 495 BC.

${ }^{64}$ Pace Christopher Tuplin, "The Coinage of Aryandes," REA 91 (1989): 77-78; and Tuplin, "Darius' Suez Canal," 265-66. Tuplin takes the Polyaenus passage quite seriously as historical evidence, but prefers to connect the episode to an unknown bull who may have died between Years 4 and 34 of Darius (more precisely around Year 17 of Darius; see Erika Schott, "Eine datierte Apisbronze," RdE 19 [1967]: 87-98). Sources that were published after Tuplin's articles render this proposition untenable: we now have sources for four Apis bulls, as well as a source which lists four Mothers of Apis for the same period. The presence of an additional bull is thus very unlikely; see Devauchelle, "Les stèles du Sérapéum": 99-108, for an overview of the Apis bulls of the period, and, for the Mothers of Apis, see Harry S. Smith, Carol A. R. Andrews, and Sue Davies, The Sacred Animal Necropolis at North Saqqara: The Mother of Apis Inscriptions, vol. 1 (London, 2011), 15-25.

${ }^{65}$ The passage in Polyaenus was already connected to the Apis of Year 4 by Alfred Wiedemann, Geschichte Aegyptens: von Psammetich I. bis auf Alexander den Grossen (Leipzig, 1880), 236. Both he and Parker ("Darius and his Egyptian Campaign") connected the episode to Aryandes' "rebellion" known from Herodotus, but 
One problem remains, however: Polyaenus wrote centuries after the events he claimed to describe, and we have no way of knowing the reliability of his account or the sources he may have used. To be sure: it is true that some of Polyaenus' passages go back to stories from fifth and fourth century BC sources, e.g., stories that we know from Herodotus and Ephorus (the latter as preserved by later authors). ${ }^{66}$ It is therefore possible that the Apis episode goes back to a much older tradition. But we cannot be certain: if the story had actually appeared in Herodotus, or any of the other Persian Period Greek authors whose works have been preserved, we could have given it more credence, but none of them mentions a similar episode. When one adds that the link between a conquest of Egypt and the treatment of an Apis bull occurs multiple times in later literature ("bad" kings, such as Cambyses and Artaxerxes III, mocked and murdered the bull; while "good" kings, such as Alexander the Great, showed reverence for it) the story becomes even more suspect. ${ }^{67}$ Polyaenus, or whoever his source was, may have simply connected another famous king of the Persian Period to the Apis bull in Egypt, in this case making Darius the "good" (or clever) king who rallied Egyptian support by respecting their customs. Whether the story is a literary trope or whether it (uniquely) preserves the memory of a real historical episode therefore cannot be definitively judged. In the absence of further and earlier evidence, the story cannot prove Darius' alleged invasion of Egypt in 518 BC.

\section{The Silence of Later Sources}

If we put aside Polyaenus as a reliable source, not much remains in terms of later memory of the Egyptian rebellion. We do have a reference in Aristotle's

this cannot have been the case, since Aryandes was still satrap of Egypt in ca. 515-513 вC (see above; see also Cameron, "Darius"). See also Yoyotte ("Pétoubastis III": 223) and Kaper ("Petubastis IV, 142-43), both of whom connect the Polyaenus passage to Petubastis' revolt (the former implicitly by assuming that the revolt was waged against Aryandes).

${ }^{66}$ E.g., compare Polyaenus Stratagems VII 34 and 44 to Herodotus Hist. IV 3 and 201. On Polyaenus' use of the fourth century BC Ephorus, see Elisabetta Bianco, "The Third Book of Polyaenus and Ephorus," in Polyaenus: New Studies, ed. Kai Brodersen (Berlin, 2010).

${ }^{67}$ Angnieska Wojciechowska, "The Black Legend of Cambyses in Herodotus," in The Children of Herodotus: Greek and Roman Historiography and Related Genres, ed. Jakub Pigoń (Cambridge, 2008), 29-30.
Rhetoric, which mentions that Darius conquered Egypt prior to his invasion of Greece, but one doesn't gain much more information from it. ${ }^{68}$ Other GrecoRoman sources remain silent on the matter, and later Egyptian sources never mention it either. ${ }^{69}$ This silence may prompt one to doubt the existence of Petubastis IV, or at least the longevity of his rule. ${ }^{70}$ But the situation is not so straightforward. For one thing, one of the oldest sources that talks about Darius' early reign is Herodotus, who wrote about a century after the Bisitun crisis. Significantly, he seems to have been largely unaware of most of the revolts which Bisitun so vividly describes, and the same applies to authors who wrote even later than Herodotus. ${ }^{71}$ Sec-

${ }^{68}$ Aristotle says that Darius only invaded Greece after he had captured Egypt, and that Xerxes did the exact same thing (Aristotle Rhetoric II 20). This gives us an extremely vague timespan for the conquest: that it might have happened at any time prior to the first (attempted) invasion of Greece in 492 BC; see Briant, Cyrus to Alexander, 156-61.

${ }^{69} \mathrm{I}$ am hesitant to connect the story of a sandstorm in Herodotus to a suppressed memory of a battle between Petubastis and Persian forces (as suggested by Kaper, "Petubastis IV," 141), which would entail the assumption that Petubastis was already active during Cambyses' reign. But Kaper is right to note that Petubastis' building in the Southern Oasis suggests a particular connection to that area, and that Darius' later building in the same oasis is therefore conspicuous (ibid., 135-37 and 143-45). Other than that, it is interesting to note that a passage on the statue of Udjahorresnet, which was made during Darius' reign, has sometimes been interpreted as an oblique reference to the troubles of Petubastis' rebellion (ibid., 138; and see already Cameron, "Darius," 310-11). Others, however, have seen it as a reference to the Persian conquest by Cambyses (Posener, La premiere domination perse, 169; Briant, Cyrus to Alexander, 56-57) or as merely a generic statement without actual historical value (Kuhrt, Persian Empire, 120 n. 14; but cf. Allen B. Lloyd, “The Inscription of Udjahorresnet a Collaborator's Testament," JEA 68 [1982]: 176-78).

${ }^{70}$ Cf. Tuplin ("Coinage of Aryandes": 76): "I cannot believe that a rebellion in Egypt [Tuplin's emphasis] which lasted from 522/1 until at least 518 and which was then suppressed by Dareios in person would be completely unknown to the Herodotean tradition"; see also Tuplin, "Darius' Suez Canal," 265, with very similar wording). Note that Tuplin does allow for the rebellion to have lasted "until at least 520," and that it may have been suppressed by Aryandes rather than Darius (ibid., 264-65).

${ }^{71}$ Herodotus only mentions an unknown rebellion by a Persian satrap in Sardis (Hist. III 126-28; not mentioned by Bisitun), and one Babylonian revolt which allegedly took twenty months to subdue (ibid. III 150-60). The next campaign that Herodotus describes is the one against the (European) Scythians, many years after the Bisitun crisis (ibid. IV 1). Herodotus probably wrote his book in the $420 \mathrm{~s} \mathrm{BC}$ or thereabouts. For the difficulty of dating the Histories see Allen B. Lloyd, Herodotus Book II: Introduction (Leiden, 1975), 61-68. For other relevant Greco-Roman passages, 
ondly, later Egyptian sources never mention any of Egypt's revolts against the Persians (except the successful one by Amyrtaios II), even though we know of their existence from both contemporary records and Greco-Roman histories. ${ }^{72} \mathrm{~A}$ similar situation prevailed in Babylonia: we are relatively well-informed about the Babylonian revolts from contemporary cuneiform records, but Graeco-Roman authors barely mention them, and later Babylonian sources remain equally silent on the matter. ${ }^{73}$ The episodes may have been too embarrassing or too politically sensitive to write about. So, if Petubastis suffered from a damnatio memoriae in Egypt (as later rebel-kings did), and if the many revolts from $522 / 521 \mathrm{BC}$ were obscure or even unknown to the Greeks in general, the (near-)absence of the Egyptian revolt in later sources is not surprising. Later silence and/or ignorance cannot be used to argue against the existence of any of the Bisitun rebellions; they may still have been significant episodes in their own time.

\section{Conclusion}

Egypt's political situation in 522/521 BC is shrouded in uncertainty. Nonetheless, the sources that we have allow for the following (tentative but most likely) reconstruction: Cambyses died (near to or far away from

see Kuhrt, Persian Empire, 158-73. Note that The Persians by Aeschylus preserves the oldest Greek reference to the Bisitun crisis, but it does not refer to the rebellions.

${ }^{72}$ Amyrtaios is mentioned in, e.g., Manetho and the Demotic Chronicle, both from the third century $\mathrm{BC}$ (Kuhrt, Persian Empire, 390-91, 393-94). For a brief introduction to the Egyptian revolts, see Rottpeter, "Initiatoren."

${ }^{73}$ With the possible exception of the Seleucid Uruk King List, which mentions an elusive "Nidin-Bel" reigning just before Darius III; see Caroline Waerzeggers, "Babylonian Kingship in the Persian Period: Performance and Reception," in Exile and Return: The Babylonian Context, ed. Jonathan Stökl and Caroline Waerzeggers (Berlin, 2015), 203-204.
Egypt) at some point after April 522 BC. Egypt may have continued to date texts to his reign or switched to Bardiya, Darius, and/or an Egyptian rebel-king in the following months, but no records have been preserved to clarify the situation. Petubastis IV probably rebelled at the turn of $522 / 521$ BC (as claimed by the Bisitun text), and ascended the throne between the first of January and April 521 BC (cf. the Meydum papyri). Darius was preoccupied with revolts in other parts of the empire until the end of that year, which gave Petubastis ample opportunity to consolidate his power from Herakleopolis all the way down to the Southern Oasis, and to propagate his rule by means of dedicating cultic objects and even building part of a temple. The absence of Egypt in the Bisitun inscription, including the addenda, suggests that it took at least two years before Darius sent a (successful) campaign against Egypt. Whether Darius managed such a campaign in 519 BC or whether it was only conducted in 518 BC cannot be resolved with any degree of certainty: the passages in P. Golénischeff, the Demotic Chronicle, and Polyaenus, as well as the silence on the Egyptian revolt in other late sources, cannot prove one or the other scenario. All we know for certain is that Egypt recognized Darius by August 518 BC.

It is clear from the minimal length of Petubastis' reign (at least two years, perhaps more than three years) and the archaeological traces which he left behind (in numbers comparable to those found for Cambyses in Egypt) that the Egyptian rebellion must have been a significant episode in the early history of Persian Period Egypt. Two to three years may not sound like much to the modern historian of antiquity, but it certainly was for the people who had to live through it. What this meant for Darius' later policy towards Egypt, and for the way that Egyptians would have viewed Darius and his Persian descendants, deserves a study of its own. 